\title{
提升学术出版水平, 服务国家科技创新战略
}

乌书林

中国出版协会, 北京 100010

E-mail: linshuwu2008@sina.com
CrossMark $<$ click for updates
近年来, 随着国家对学术出版扶持力度的不断加大, 我 国学术出版发展正面临良好机遇. 在此背景下, 我们应认真 研究总结国际国内学术出版经验, 准确把握学术出版属性, 关注国际国内进展和趋势, 推动学术出版繁荣发展.

\section{1 中国学术出版发展正面临良好机遇}

第一，党中央高度重视为建设出版强国指明方向. 2018 年11月, 中央全面深化改革委员会第五次会议通过 《关于深 化改革 培育世界一流科技期刊的意见》 (以下简称《意 见》), 指出: 加快建设世界一流科技期刊, 夯实进军世界科 技强国的科技与文化基础. 2019年8月，《意见》正式发布. 2019年9月，中国科学技术协会等七部门联合组织实施了“中 国科技期刊卓越行动计划”. 2020年10月，党的十九届五中全 会审议通过《中共中央关于制定国民经济和社会发展第十 四个五年规划和二 $O$ 三五年远景目标的建议》，提出：构建 国家科研论文和科技信息高端交流平台; 建设国家数据统一 共享开放平台，保障国家数据安全．2021年5月18日，中宣 部、教育部、科技部印发《关于推动学术期刊繁荣发展的 意见》. 这些政策的密集出台, 为新时期学术出版的发展指 明了方向, 创造了有利的环境.

第二，经济社会快速发展和巨大的经济规模提供了坚实 基础. 根据国家统计局数据，1978 2020年我国GDP总量从 0.37 万亿元跃升至 100 万亿元，实际增长了 269 倍多. 综合国 力的大幅提升是出版业快速发展的前提和基础.

第三, 教育的全面繁荣发展提供了良好的人力资源条件. 目前我国在校大学生人数为 4000 多万，有 2.18 亿人受过高等 教育, 我国博士研究生的数量已位居世界前列. 教育水平的 提高不仅为我国的出版事业涵养了广大读者, 也为内容生产 提供了源源不断的作者.

第四，研发投入的稳步增长为建设出版强国提供不竭的 内容来源. 改革开放以来, 我国实行科教兴国的基本国策, 科 学研究繁荣发展, 科研创新成果不断增多, 既促进了经济社 会的发展, 又为出版繁荣提供了重要的内容资源. 近年来, 中 国的研发开支大幅增长，从2000年的896亿元增长到2020年 的 24393 亿元, 位居世界第二, 仅次于美国.

第五, 巨大的论文产出数量为建设出版强国提供了现实

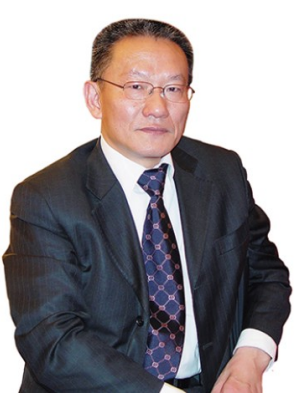

邬书林中国出版协会理事长. 国 家创新与发展战略研究会学术委员 会委员. 南京大学、武汉大学、北京 印刷学院兼职教授.1982 2004年任 中宣部出版局期刊处干事、副处 长、处长、副局长、局长; 2004 2014年任国家新闻出版总署副署长. 2010年哈佛大学高级访问学者.

基础. 据Scopus数据库统计显示，2019年度全学科总体发文 量中国与美国持平，2019年后，中国超越美国(图1); 同时，中 国的2019年度全球高被引1\%论文占比达到世界第二位.

第六，健全的出版体系和积累的出版经验提供了重要保 障. 改革开放以来, 我国出版业自身有了长足的进步, 建立了 相对完整的出版体系，初步适应了我国经济和社会发展. 目 前, 每年出版报纸1800多种; 出版图书近50万种, 其中新书有 20 多万种; 出版期刊有 1 万多种. 通过历次出版五年规划(计 划)的实施，规划出版了一系列反映当代中国政治、经济、 科技、文化、教育和社会生活等各个方面的重点图书.

\section{2 研究总结国际国内学术出版经验, 准确把 握学术出版属性}

\section{1 世界学术出版发展史的经验}

现代学术出版350多年来的发展演变历程带给我们的启 示有:

第一，学术出版是在科技文化创新日益重要的背景下产 生的. 其重要的社会功能是发表创新成果, 推动创新发展, 学 术期刊发表的应当是科学研究和经济社会发展过程中的思 想创新、科学发现、技术进展、管理经验的成果.

第二, 学术出版中坚持科学精神、学术出版质量和市场 运作并行不悖. 目前, 世界上最高水平的学术期刊往往是定 价最高, 或者收取文章处理费(APC)最高的期刊, 而取舍的标 准, 是有无创新和学术质量.

第三，学术出版、研发投人、经济发展的相互关系. 从 


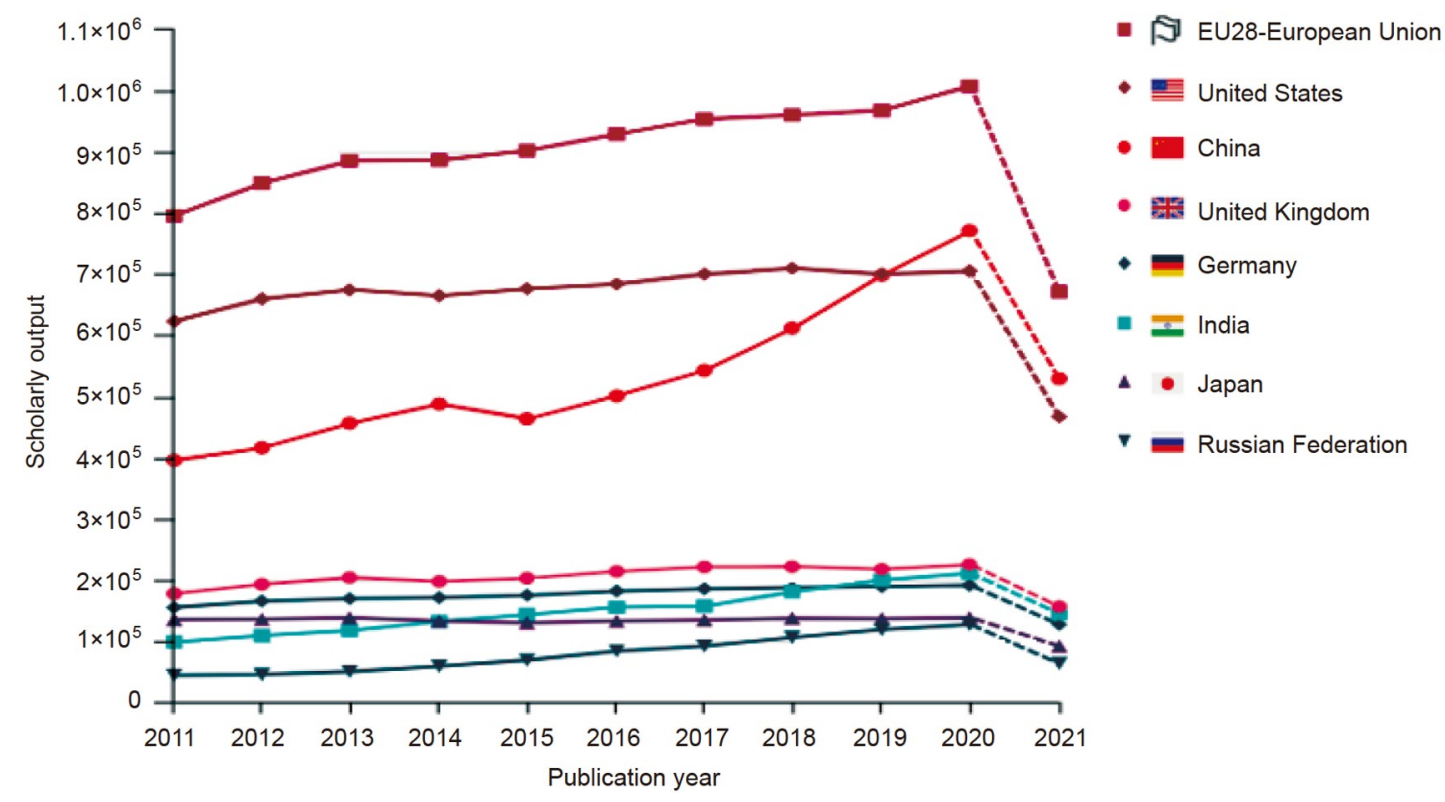

图 110 年间全学科总体发文量最高的几个国家/地区的变化情况. Scopus/SciVal数据库, 检索日期: 2021-08-23

Figure 1 Changes in several countries/regions with the highest number of publications in the overall disciplines in the past decade. Scopus/SciVal database, retrieval date: 2021-08-23

世界几大主要经济体来看, 多将GDP的3\%用于研发投人, 而 研发投人的 $1 \% \sim 2 \%$ 用于学术出版.

第四, 高水平的学术出版一开始就是国际化的. 世界学术 出版随经济和科研中心的转移而转移. 世界学术出版中心, 最 早在意大利，其后转移到法国、英国，目前在美国. 中国不应 当丢失经济社会发展带来的成为学术出版中心的可能机遇.

第五，学术出版有了严格的科学规范. 学术期刊论文的 发表过程, 已经深深地融人科学研究、经济发展之中, 并且 随着信息技术的进步, 变得互动、方便快捷和不可或缺.

第六，学术出版是一个国家在世界上赢得话语权、赢得 尊重的重要阵地和平台, 因为科学话语、学术话语往往能克 服意识形态的障碍.

第七，学术出版风气正常与否，反映着学术界和文化界 的风气, 也反映着社会风气. 学术风气、文化风气好不好, 关 乎当代, 影响未来.

\section{2 改革开放以来我国出版业发展的经验}

在内容生产上，我们自觉把传播古今中外一切优秀思想 文化成果作为出版的重要功能, 是改革开放以来我国成为出 版大国的一个重要经验. 要“坚持古为今用、洋为中用, 融通 各种资源, 不断推进知识创新、理论创新、方法创新”, 要“坚 持不忘本来, 吸收外来, 面向未来, ${ }^{,[1]}$.

第一, 不忘本来. 新中国成立以来, 特别是改革开放以来, 我们系统全面地整理了我国的思想文化遗产. 改革开放之初 就恢复成立了“国务院古籍整理出版规划小组”. 在文化普查
的基础上形成了 24 万多种古籍书目, 并进行有计划的整理工 作. 在过去的 70 年中, 特别是近 40 年中, 我们总共整理出版了 35000 多种中国的典籍, 规划实施了多项古籍出版工程, 如二 十四史、善本再造工程, 并与时俱进地推动对中国文化的深 人研究, 如《中国思想家评传》(200卷).

第二, 吸收外来. 近百年来, 特别是在过去的 40 年中, 中 国全面、系统、准确地翻译出版了世界各国的优秀文化经 典, 如饥似渴地学习、研究、借鉴西方的科技文化. 现在从 古希腊到当代世界各学科、各学派的重要经典和代表作几 乎都有了中译本，如商务印书馆《汉译世界名著》(800多 种)、上海世纪出版集团《当代政治学术著作丛书》和《国 际政治关系丛书》等, 翻译出版了《柏拉图全集》《莎士比 亚全集》《爱因斯坦全集》 《丘吉尔回忆录》等. 中国每年 新引进国外图书版权达15000多种(http://www.nppa.gov.cn/ nppa/upload/files/2020/11/a0fbd38dab39dd1f.pdf), 有不少图书 的中文版与英文版同时出版.

第三，面向未来. 我国出版事业的发展离不开一系列高 瞻远瞩的战略部署，包括制定文件、明确方针政策、制定规 划、提供良好环境、培养人才等各个重要方面.

\section{3 准确把握学术出版的属性}

国际国内的学术出版经验告诉我们: 学术出版是科学研 究的有机组成部分、是文化工作的重要领域、是文化产业 的核心板块, 学术出版要健康快速发展, 三者必须紧密结合, 缺一不可. 


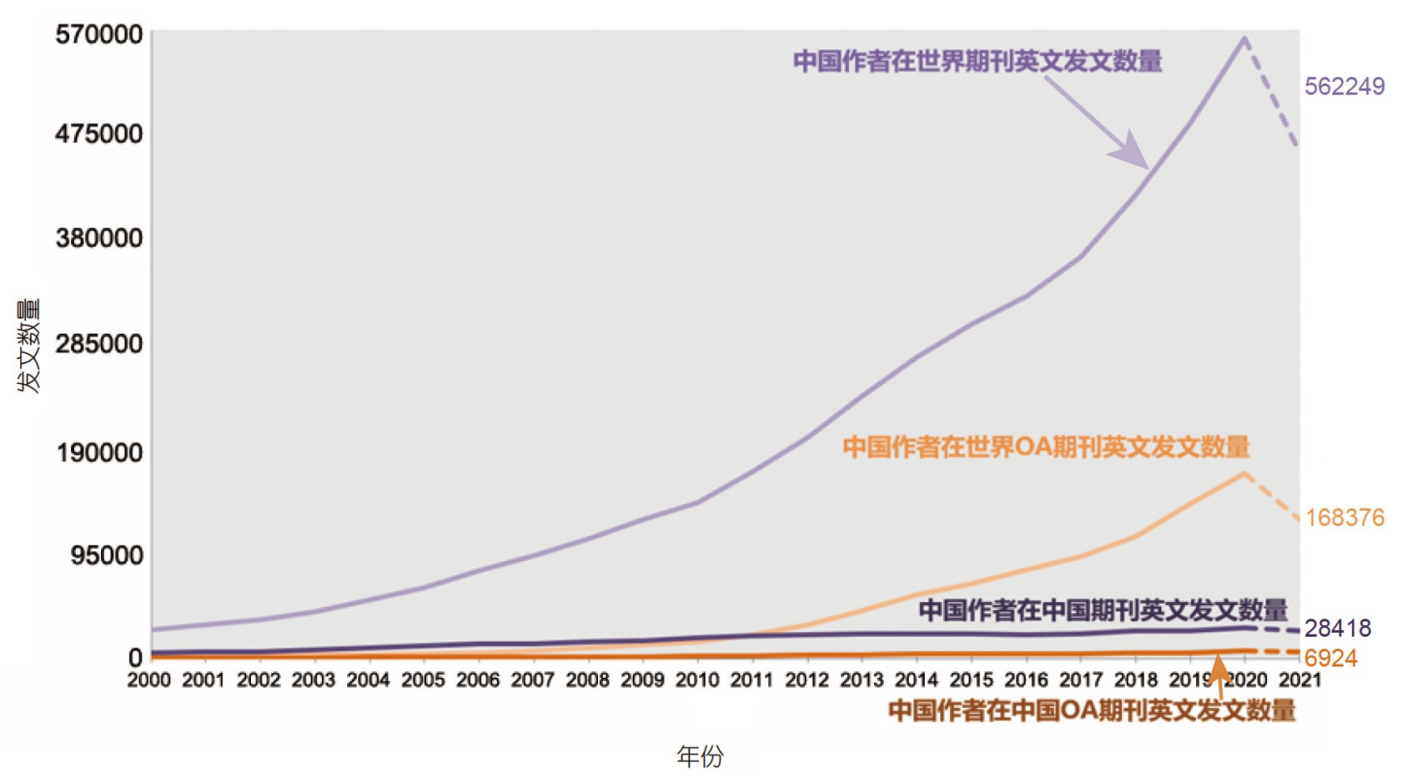

图 2 中国作者在全球及中国期刊英文论文发文情况. Scopus数据库, 检索日期: 2021-08-23

Figure 2 Chinese authors' English-language papers published in global and China's journals. Scopus database, retrieval date: 2021-08-23

\section{3 关注国际国内进展和趋势, 推动学术出版 繁荣发展}

第一，关注数字技术的新进展. 信息技术的革命性进步 为我们提升出版水平提供了机遇. 人工智能、大数据、区块 链的应用使出版的理念、管理方式、载体形式、传播方 式、运作流程、服务方式都发生了巨大变化 ${ }^{[2]}$, 我国的学术 出版要紧跟技术发展的最新潮流.

第二，国际学术出版的集中度在提高. 以施普林格・自 然(Springer Nature)、爱思唯尔(Elsevier)等为代表的国际著 名大型出版集团出版了世界上最多的学术期刊，拥有一系列 著名期刊品牌并形成了庞大的刊群，而且近年来学术期刊向 大型出版商不断集聚的趋势愈加明显 ${ }^{[3]}$.

第三, 开放科学对出版业的影响. 传统高质量期刊向 $\mathrm{OA}$ (开放获取)转型, 表示对OA出版模式的认同 ${ }^{[4]}$. 如2020年, 施 普林格 - 自然宣布Nature系列期刊可实行开放获取政策. 同 年, 爱思唯尔宣布Cell Press的期刊为作者提供开放获取选 项. 基于Scopus数据库，对近 10 年中国与世界其他主要科技 论文产出大国OA论文数量比较, 结果显示, 10 年里, 中国OA 论文数量排名从全球第 4 位前进到第 2 位, 并逐渐拉开与第二 集团的差距. 此外, 2020年, 中国作者在全球OA期刊发表英文 论文168376篇, 其中在中国OA期刊发表英文论文6924篇, 意
味着目前中国OA期刊仅能承载 $4.1 \%$ 的中国OA论文, 提示我 国应当加大创办英文 $O A$ 期刊的力度(图2).

\section{4 中国学术出版应有高远的立意}

世界历史反复证明，随着政治变革、思想解放和重大科 技创新带来的经济社会发展往往会逐步使一个国家或地区 成为世界经济中心, 经济中心的形成又会进一步促进文化和 科技的繁荣与发展，在这个过程中产生的大量知识和信息， 成为人类的宝贵精神财富，这种状况在世界近代历史发展中 更为明显. 在我国经济社会取得大发展的今天，如何把握可 能的世界学术出版中心的机遇, 值得我们深人思考.

当前, 专业出版已经历了从纸质出版, 到在线数据库、 数字决策工具的发展路径, 并形成了成熟的现代学术出版流 程. 我们既要认真学习借鉴国际学术出版的先进经验, 也要 实事求是地总结分析改革开放以来国内学术出版的经验和 问题, 要充分认识到学术出版对于推动科技创新和经济社会 发展的重要意义，把提升我国科技期刊出版水平作为大事去 抓 ${ }^{[5]}$, 不断提升我国学术出版水平, 以更好地服务国家科技创 新战略，为我国科技高水平自立自强提供有力支撑. 在中华 民族伟大复兴的进程中，建立相对完整又参与国际竞争的出 版体系，为中国经济、科技、文化发展和构建人类命运共同 体服务, 中国出版人应当有这样的追求和立意.

\section{推荐阅读文献}

1 Xi J P. Speech to a symposium on philosophy and social sciences (in Chinese). People's Daily, 2016-05-19 [习近平. 在哲学社会科学工作座谈会 
上的讲话. 人民日报, 2016-05-19]

2 Shen X B, Liu H X, Wang H J, et al. Seven technological trends to promote the innovation and development of scientific journals (in Chinese). Acta Editol, 2021, 33: 129-132 [沈锡宾, 刘红霞, 王海娟, 等. 刍议推动科技期刊创新发展的7大科技趋势. 编辑学报, 2021, 33: 129-132]

3 Wang W, Huang Y H, Ren S L. Clustering development of international publishers and inspirations (in Chinese). Chin J Sci Tech Period, 2021, 32: 596-600 [王维, 黄延红, 任胜利. 国际出版机构期刊集群化发展及启示. 中国科技期刊研究, 2021, 32: 596-600]

4 Gao Y. Investigation on the OA publishing of scientific journals (in Chinese). Acta Editol, 2020, 32: 112-117 [高洋. 科技期刊OA出版的文献计 量分析. 编辑学报, 2020, 32: 112-117]

5 Wu S L. Improving China's scientific publishing is imperative (in Chinese). Chin Sci Bull, 2018, 63: 3163-3166 [乌乌阝或林. 提高我国科技期刊出版 水平是一件大事. 科学通报, 2018, 63: 3163-3166] 


\title{
Improve academic publishing and serve national science and technology innovation strategy
}

\author{
Shulin $\mathrm{Wu}$ \\ The Publishers Association of China, Beijing 100010, China \\ E-mail: linshuwu2008@sina.com
}

In recent years, with the increasing support for academic publishing in China, the development of academic publishing in China is facing good opportunities. Under this background, first, we should conscientiously study and summarize the experience of international and domestic academic publishing, accurately understand the nature of academic publishing, which is an integral part of scientific research, an important field of cultural work, and the core sector of cultural industry; second, to promote the prosperous development of academic publishing in China, we should pay close attention to the international and domestic progress and trends, including the new advances in digital technology, the high concentration trend of international academic and professional publishing, the influence of open science on the publishing industry, etc. At present, professional publishing has experienced a development path from paper publishing to online databases and digital decision-making tools and has formed a mature modern academic publishing process. We should not only learn from the advanced experience of international academic publishing, but also realistically summarize and analyze the experience and problems of domestic academic publishing since the reform and opening-up, fully realize the significance of academic publishing in promoting scientific and technological innovation and economic and social development, and continuously improve the level of academic publishing in our country, to better serve the national scientific and technological innovation strategy and provide strong support for our country's high level of self-reliance in science and technology. Finally, Chinese publishers should have lofty pursuits, strive to establish a relatively complete publishing system that also participates in international competition, and serve China's economic, technological, and cultural development, and the building of a community with a shared future for mankind.

academic publishing, scientific and technological innovation, China's opportunity, international and domestic publishing experience

doi: 10.1360/TB-2021-1213 